\title{
Transformations of the Dissident Behaviour. Politics in Post-1989 Bulgarian Literature
}

\begin{abstract}
Licheva Amelia, Transformations of the Dissident Behaviour. Politics in Post-1989 Bulgarian Literature. „Poznańskie Studia Slawistyczne” 6. Poznań 2014. Publishing House Science and Innovate, pp. 279-290. ISBN 978-83-63795-51-1. ISSN 2084-3011.

The essay follows the changes in the literary works of the Bulgarian dissidents immediately after 1989. It tries to take into account the disillusionment and the distorted perceptions, but also the satisfaction of freedom, which it discusses as subject matters in the poetry of two dissident authors, who were also active politically - Blaga Dimitrova and Edvin Sugarev. The second major line of thought in the essay is a rereading of socialism in the writings of the younger generations. Against the backdrop of a major absence from Bulgarian literature during the socialist regime, it is interesting to observe how the new generations compensate the gaps, and what they stress on, including in those cases when they try to render socialism into a convertible currency.
\end{abstract}

Keywords: dissident authors; politcs; literature; socialism; new generation

The subject of death camps, and in a broader aspect, of fascism as a government regime and an ideology, remained a constantly present political theme throughout the development of literature in the second half of the $20^{\text {th }}$ century. And despite the abundance of texts dealing with that particular subject matter, it still has a place even in the most contemporary of novels. A good case in point in recent years have been Bernhard Schlink's The Reader (original title, Der Vorleser), John Boyne's The Boy in the Striped Pyjamas and Jonathan Littell's The Kindly Ones (original title, Les Bienveillantes). And if in Boyne's novel the political has been interwoven into the parable, both in The Reader and in The Kindly Ones the political has acquired almost documentary dimensions. In other words, it cannot be argued that because of the years that have elapsed and the experience that has faded, the degree to which the political projects itself into the fictional will also decline. On the contrary, the desire for veracity continues to be of interest to 
contemporary writers. A similar statement can be made about other political issues that have become an obsession with fiction writers. Such topics are communism and the totalitarian regimes in general, and most recently 9/11, as well as the latest developments in Iraq, Egypt, India etc. Communism has been a predominant subject matter in Eastern European literature (and in European fiction in general), and a multitude of plots have been based on it, beginning with Milan Kundera, and ending with a constellation of writers in each of the national literatures of the East European states. An illustration of the latter is the Nobel Committee nod to Herta Müller, a writer whose novels are based on facts from the history of the totalitarian regime in her native Romania and its specific features. As far as 9/11 is concerned, some writers have used it either to reflect on the state of the contemporary world and the repetitiveness of horrendous events that cause death by the thousands (Nancy Huston's Fault Lines, original title Lignes de faille); or to discuss the detrimental effect of the political on the individual (Jonathan Safran Foer's Extremely Loud and Incredibly Close); still others incorporate it into the construction of anti-utopia's (Paul Auster's Man in the Dark). And finally, the novels of Khaled Hosseini, Arundhati Roy, Jhumpa Lahiri, and Ala al-Aswani are set into a larger political context that allows for the accumulation of knowledge on the history of the countries they have been writing about.

If we take a look at contemporary Bulgarian literature, we shall be able to trace some interesting correlations with politics, but after 1989. Prior to that year, politics seemed to be a forbidden subject matter for literary works. Naturally, some authors like the famous writer of satires Stanislav Stratiev made certain political hints, or included references to western societies and their decadence, or to the guerrilla movement and its role, but neither contemporary politics, nor the politicians of the day featured in the literary texts at the time, with the exception of a few poems and their political dedications. That is why the change that took place after 1989 was so dramatic.

One thing worth noting of the early years after the onset of democratic changes is that literature, and poetry at best, was actively fed subject matters by politics. The writing of two Bulgarian poets known as dissidents - Blaga Dimitrova and Edvin Sugarev - has become emblematic in that respect. We chose those two because they are one of those who illustrate 
best the symbiosis between literature and politics that took place in the described period. Both were actively engaged in politics (Edvin Sugarev was a member of parliament, and Blaga Dimitrova was a vice president), but at the same time they were one of the leading columnists of the period, and altogether, they never stopped writing poetry, some of which can be termed as having made certain commitments.

Both have written poems dedicated to Bulgaria and the emerging democracy. These poems are a record of sorts of the political, which echo with the moods of the time - enthusiasm, optimism, a feeling of upsurge and activity at first, followed by confusion, disillusionment and sadness.

One of Edvin Sugarev's most representative poems is entitled When (Bad Dreams). It reveals an enormous faith, and is a utopia of sorts of what has been expected, of the new order that will be established. In terms of power and pathos it is not inferior to the utopias of the classic poets Hristo Smirnenski and Nikola Vaptsarov, but shows a different tendency from theirs, and offers an exactly opposite kind of utopia from theirs, and certainly one that crosses out the vision of ,the bright future".

The change in When is represented by the image of the wind that turns the world upside down. The vision is an apocalyptic one - the wind is so powerful that it roots out trees and deprives everyone and everything of the status quo they had become comfortable with. The old world of silence and „crab-walk" has been overthrown. Moreover, the change is of cosmic dimensions - death and life are overturned and exchange places, the past (seen as a tradition from which we have been severed by force) receives its due place. Salvation, resurrection and renaissance are in progress.

And, meanwhile, the world and its inhabitants have been entitled to a voice, because the ,tongues grown into the palate" acquire certain rights and begin to act, i.e. to produce meaning. It is the end of the shenanigans, the marionettes, who had become accustomed to simply clapping their hands, „the spiders have been caught" that had been spying on the word. The change has been identified to the right to a voice, to a new language and freedom of expression. It is an opening of the senses, a birth of new experiences, of hope, and a manifestation of longing and a resurrection of human dignity.

Change as apotheosis of light and the establishment of a new idiom is a characteristic trait of Blaga Dimitrova's poetry, too. In her poems written 
at the end of 1989 and in the early 1990s, she introduced the oppositions: darkness - light (Night Time Diary), stressed out that „language has broken down the padlock" (Current) and pointed out that what was happening was accompanied by a cry of help on behalf of the motherland, and that the decent behaviour in that case was to leave everything behind and renounce the old, and that the self ought to answer to the requirements of the country by committing itself to matters of public interest.

With time the reflections of the political altered, and as was mentioned earlier, it stormed poetry mainly as disillusionment. The poems dedicated to Bulgaria and the Bulgariannness became records of unfulfillment, lack of change, disparity with dreams. Edvin Sugarev's collection of poems Motherland was very representative in that respect. It saw Bulgaria in a variety of images that were all references to failure, inertia, and the lack of normal life. Bulgaria was a „puddle” (Worms), it was the pain at the absence of a future, and a present (Being); Bulgaria was a „blank” (Unknown Lands), a „messy-unlaid tablecloth", where the only easily recognizable things were the profiteering, the onlooking and the spectacle (Uneasy, Somehow). But ultimately Bulgaria was a „paroxysm”, „mud”, ,quagmire” (Swallow Nests). Nothing was left of the initial hopes and dreams (,matted dreams and squashy hopes"), the bitterness and the sarcasm had given birth to an ultimately unorthodox image of the Bulgarianness charged mostly with negative emotions.

Dimitrova's negativism is most evident when she touches on freedom, one of her favourite subjects. In the poems written in later years freedom seemed to have lost its abstract quality and was directly inspired by the political. One of the leitmotifs in A Day - A Life was the using up and wearing out of words, including of the word ,freedom” itself. Why, the poetess asked, did it turn out to be ,the most foreworn, the most defamed" word, and not merely the longest dreamt of and the most eagerly anticipated? And she found the answer in freedom's dependence on what was happening outside, among the people in society. Dimitrova's poems ascertained that in order for freedom to exist, it was not enough that it expressed a willpower or a longing; its existence required circumstances and situations, where it could thrive. However, taking as a starting point the early years of democracy and the development of the political, she noticed rather the wasting and compromising of freedom - the speculators mistook it for advertising, 
the tabloids took to disgracing it; the majority abused it and thus, it became a scurge, a license, when it ought to have become a dream. It turned out that freedom was not devoid of ambivalence as it could serve to libel, to disgrace, to dishonour and to stigmatize, and that the only thing deprived of freedom was truth. Every one who tried to speak their minds found themselves with their mouths shut, despite the fact that the means of shutting one's mouth had become more sophisticated.

In the poem Exile from the collection From Scratch Again taking as a starting point the political meanderings of Bulgaria inside the country, and in its relations to the West, and the ever expanding number of people leaving the country, Blaga Dimitrova drew the picture of a country with a withered soul, a ,wanderer at a crucified crossroad". While in Salvaged (By the $E d g e$ ) she put the change in words, and depicted it as a characteristic trait of interpersonal relations soon after the democratic changes, and the disillusionments and the curses that accompanied the social life and the „crucified" hope.

When we discuss the projections of the political in Blaga Dimitrova's poetry, we cannot dismiss the fact that her poetry has always been turned towards it, regardless of the names it has been given. That is why it is no coincidence that it continues to exist in her later poems not only by means of domestic, but also foreign influences. Her poems reflected on the events of 9/11, the blood bath in Bosnia and Kosovo, and the fate of the old and the new century.

Dimitrova saw 9/11 (11 September 2001) as a crisis of the primeval language that could no longer name values like rationality, justice, peace and freedom. It had been given a new meaning as the repetitiveness that deleted the difference between the old and the new century (The Century of the 3 - Isms, Totally in Vain), and left only one common feeling - fear. What is more, in the afterword Well... to her poem Totally in Vain, Dimitrova presented the events of the new century as a global expansion of the hatred and as accumulation of the death and the fear, i.e. as a culmination of the evil piled up throughout the $20^{\text {th }}$ century.

The tragedy in the Balkans, to some extent an integral part of the collective frenzy and the expansion of death, was reflected in another of her later collection of poems Balkan Games - Inferno, where she turned political events and situations such as the massacres in Bosnia, the war, the ethnic 
cleansing, the refugees' fate, and the very names of Bosnia and Kosovo into poetry subject matter. She criticized the West for responding quickly when it came to oil, but lagging behind when it came merely to bloodshed, and spoke in general of the fate of the Balkans and their doom (Balkan Games, Balkan Cross). She even hinted that what was happening in the Balkans could be the end of Europe, because there was nothing easier than a process of Balkanization of Europe, which would translate in „oppression, quarrel and bloodshed”, as well as into the proverbial „Bulgarian umbrella”.

But it will be interesting to track down in this earlier period, which we defined as a symbiosis between politics and culture, the reverse influence of literature over politics, whose most precise manifestation can be found in the widely spread genre of non-fiction. And by non-fiction we mean here also the political speeches, because a great many of them in the early 1990s did not differ significantly from non-fiction, probably because they were delivered and drafted by prominent intellectuals. An emblematic example is Stefan Savov - a politician, but also a renowned translator of works of fiction from Spanish.

Overall we could argue that non-fiction borrowed plots and characters from fiction (in most cases Aleko Konstantinov's Bai Ganyo), and used rhetorical approaches typical of literary works (hyperboles, retardations, oxymoron's, and enhanced use of tropes), but developed its own fictional plots with the purpose of attracting the readers' attention to the burning issues of the day - democracy, freedom, citizens' rights, the stand of the intellectuals, and the ideas for the future that had to be based on reasonable and achievable goals. Literary references became frequent - titles such as „The Taming of the Shrew" and catch phrases such as ,the winter of our discontent" became popular. Names of renowned writers like Atanas Dalchev, Václav Havel and Aleksandr Solzhenitsyn were often quoted.

This type of non-fiction filled the newspaper columns, but it did not stay only with the written word and the reader. The non-fiction texts of that time were bound to be read aloud (at rallies, in parliament), hence their enormous popularity and significance. Because, and we shall repeat it one more time, those were texts written by humanitarian scholars who resorted to literary ways but to purely political ends.

It is worth pointing out that once the political haggling settled down, and political life became professional, the intellectuals returned to their 
previous occupations and withdrew from the actual politics, but the political never ceased to play a role in literature. Moreover, it remained significant, but the genres where it was dominant changed. Without any doubt, ever since the dawn of the new millennium, the novel became the ground on which the political projected itself on literature most prominently. Fiction was dominated by a succession of novels, which turned to the past and used the political at the level of plot, characters, vocabulary, etc., as if to compensate for the absence of pronounced dissident literature in Bulgaria. Here are a few examples that demonstrate various uses of that past: Ruzha Lazarova's novel Mausoleum (written in French and published as Mausolée by Flammarion, Bulgarian translation by Rennie Yotova, Ciela Publishers) was part of the expats line, who wrote about the past and used the political as a starting point; Georgi Tenev's novel Party House intertwined the political into the experimental; while Virginia Zaharieva and Sylvia Choleva chose to confront the political with the Self and the projections of the political on the Self.

In her novel Mausoleum Ruzha Lazarova tried to incorporate into the plot the entire political history of Bulgaria from 9 September 1944 till after the decades following the fall of the communist regime. In order to make this work, she wrote her novel as a saga tracing the lives of three generations. Thus, the novel mentioned the outrages of the guerrilla movement, the cleansing of intellectuals after the 9 September coup d'état, the death camps, the labour camps, the activities of the party officials and the Popular Front militants, the confiscation of private property, the recruitment of snitches, the manifestations and the visits to Georgi Dimitrov's mausoleum etc. That is why the Bulgarian reader might perceive the novel as a concise history course, despite the fact that the plot and the characters are relatively full-blooded. But Mausoleum was written mainly for the foreign (French) readers, it fulfilled the task of serving as a piece of reading that revealed what the regime was like, and most importantly how it reflected on the fate of people. And it wished to do so now, because literature failed to do it when the regime in question was in power. Bulgarian literature had no voice like Kundera or Havel, to shout out about what was happening in the country.

In great detail the novel traced how politics broke into private lives and how families fell apart, how members of the family confronted each other because of personal preferences, how life was not precious at all, what the 
price of resistance was, and how people upheld their tiny personal revolts and disagreements, and what fear did to people. Indeed, even though the compression of all the crimes the communist regime had committed into the history of two families was a little bit exaggerated, and to the Bulgarian reader some of the events the novel described sounded two-dimensional, nevertheless Mausoleum carried out its task and became a novel that the future generations of Bulgarians who know little or nothing at all about the period in question ought to read. Because the angry direct outbursts of the narrator, the caricature of the language and the ideology, the silliness of communism, and the loyalty to the absurdities of those years make it not just a socially committed novel, but a novel with a long-term mission.

The other novels we are going to discuss also fall into the line of ,compensatory" readings, whose purpose is to wash away the shame of the almost non-existent literature from the editors' 'drawers'.

Georgi Tenev's novel Party House skilfully recounts the story - the story of a meeting (perhaps it is about love, but this novel does not allow much for the absoluteness of feelings), which gathers everyone in one book - the children of former party officials, the ,normal” youth, and the party officials themselves. Behind the generalized characters other stories gape open, which are inevitably about the symbols of the world „of once" - the mausoleum, Chernobyl, Bulgarian-Soviet friendship, the privileges, the Komsomol. At first glance there is nothing new or unorthodox about that, although Tenev appears rather lonely in his choice of stories, because the accents through which he reflects on socialism, and most of all Chernobyl, are not typical of novel writing. But the truly innovative thing is the very structuring of the novel itself. Party House relies to a greater extent on the description of dreams (nightmares) and what is going on in the minds of the characters, which makes it closer to the modern novel. At the same time, its structure is typical of the postmodern novel, with the pasting of collages from the jargon of the political and social life, the scientific papers, the journalistic writing, and in particular, documentalism proper. And yet, unlike other novels dealing with the same subject matters, Party House is very cautious of non-fiction, because the author wishes as much as possible to maintain an objective tone, which will help impose the absurdity of the stories and the themes. Tenev could have easily slipped into the non-fiction writing mode, and could have started ardently describing the untenability of 
the former regime, the Chernobyl nuclear disaster, the privileges of the ones in power, and the idiocy of the pioneer youth camps. However, he chose a different tactic. He stuck to the documentary, which he doubled with specific stories, and thus, he made a cold-bloodied suggestion about the absurdity of life in socialist times. We could even argue that in that respect Tenev followed Kafka's style, relying on the absurd, on the accumulation of details that laid bare a world void of meaning and humaneness. That is why the language has been stripped to its rawness, and only at times, gets out of breath and sends out signals that it will describe the unthinkable.

The black irony, the diary format in some parts, accompanied by the mentioned almost documentary remembrances make Party House one of the powerful books of recent years, which tries to answer the question what had happened to us in all those years of socialism, when we endured to be silenced, standardized, and sacrificed. And its reading crashes the nostalgias proving that amnesia helped the reproduction and the restoration and that there can be no pardon for the loss of human time.

Both Virginia Zaharieva and Sylvia Choleva chose to construct their novels around how the Self remembered socialism. And because in most cases it was about the Self of a child, the political was conceived not so much as a pile of facts, but rather as sensations and perceptions, it was what had permeated the families and slowly and unobtrusively was eating away at them like rust.

The entire first part of 9 Rabbits is made up of recollections. As in many other texts that emerged in the past decade, Virginia Zaharieva's novel is strongly obsessed with the attempt to explain the past and to give certain heroic undertones to the ordinary people of that time. It is a real cornucopia - life in the countryside, material shortages, recipes for dishes that were possible to cook given the shortages, but also ways to outwit the regime, silent resistances through religious faith, telling on other people, being loyal citizens of the state, the Prague Spring. In brief, the author has represented the livelihood and the mentality of the people in socialist times, but through the eyes of the child who isn't that much aware of everything going on. Therefore, there is no excess of pathos, no passages that describe the author's stand; the text relies on the narrative, whose task is to get the readers familiar with the atmosphere of those years, and also to demonstrate how those who thought otherwise and believed otherwise managed to survive, 
and ultimately, to point out how badly this regime impacted the people in terms of fulfillment, but also in terms of interpersonal relations and even as a way of cultivating a certain sensibility. Meanwhile, the story of the past is told by a young girl, who learns the lessons and rules in life at the time and fills them with experiences of her own, enough to guarantee her a complex and unsettled life as an adult. Because this book suggests - and here we cannot help but refer to the psychoanalytic preferences and practices of the author - that the recollections of the child inevitably leave their imprints on the behaviour and the thoughts of the mature individual. The novel 9 Rabbits is about the trauma that is slow to get over, about the difficulty in achieving one's inner freedom (because of the many examples of non-freedom one has witnessed), and about the desire to travel abroad as an antidote to the stagnation of socialism. It is a story about the difficulty of becoming a new personality in times of changing conditions, and suggests indirectly that the change in society can also be very difficult because of the accumulated habits, the inertia and the acquired patterns of dependence and fear.

Sylvia Choleva's novel Green and Golden also recounts the past through the eyes of a child, but it rather sees it through the eyes of the grown-up woman this child has become. Written as a diary it presupposes an emphasis on the subjective experiences of the past, on the personal echoes, and the refraction of the common in the personal story. Parallel to the personal point of view, the novel relies also on the documentary, inasmuch the story it tells relies to a great extent on the photographs which help its reconstruction, i.e. not only does it touch on personal experiences and recollections, but also relies on the memory aided by the facts captured in those photographs. However, Green and Golden wins the reader with the incredible delving into the Self as deep as possible, with the confessions of the Self about itself and its time. Some of these confessions are about the childhood years of the woman-narrator, and the life of her parents and relatives, and their friends. Sylvia Choleva does not include major historical events that have become generalizations of the socialist times; she is interested primarily in the tiny details that marked the livelihood and the mentality. That is why she speaks of the shortages, the absence of articles to buy, of „luxury” items such as coffee procured by some chance business trips abroad, the emblems of socialism - the Ideal chewing gum, the Inka coffee, the lemon jellies, the Karamel-Mu marshmallows, etc. In this vein she describes also the school 
uniforms, the almost identical clothes in the shops, the shortage of toilet paper and its replacement with carefully cut newspapers, the long lines in front of bookstores. At the same time the photographs used to reconstruct the stories have captured, also moments of personal achievements and personal satisfaction of the people in them; that is why Sylvia Choleva poses the question about the ambivalence of socialism in the experiences and perceptions of the people. And this is where her novel keeps the good measure and is most precise about: to the people in socialist times this question came down mostly to the desire to arrange oneself in life - in terms of livelihood, in terms of professional career, in terms of Communist Party membership. That is why instead of talking about nationwide resistance and making up personal biographies as most of the other novelists (and not only novelists) did, Sylvia Choleva presented generations, whose utmost goal was a cosy life and material success, and who were very much content with the occasional business trip abroad or a purchase from the duty-free shops operating with convertible currencies, the „Corecomm”. The hidden blame or rather ascertaining of the author is that these people purposefully learnt to live with what was possible and available, and never even considered what might have happened had they chanced to get out of their prison and cross the border. They had let themselves be subject to the socialist state, which, the novel stressed out, took care that its citizens be well trained and well fed. Thus, Green and Golden maintains, the socialism of the masses, the one that has still cast its shadows over the habits of several generations, and which cannot be rooted out by the removal from power of a single political party, is identical to the life in the exemplary zoo, where fear, resignation and obedience have risen to a cult status. No wonder then that most people chose consciously to ignore any mention of Belene and the labour camps, or any other transgressions of the former regime. They took socialism for granted and never questioned its eternal existence.

Naturally, Sylvia Choleva depicts also other layers of socialism that suppressed the humans in a rather dramatic way - the persecution of religious faith and church-goers, the expropriation of private property by the state and how it reflected on the owners, as well as the small-scale resistances of the personal talks, in search of spirituality or the frantic desire to uphold some kind of otherness. If we try to summarize, Green and Golden is probably the least likely of the discussed novels to present socialism as a showcase for 
foreigners. It does not go into excesses, it does not exaggerate, but rather preserves an authenticity, to which everyone who has lived under that regime can relate and easily recognize. And finally, this is a novel which is less interested in socialism as being the regime of the privileged people, but rather as a rule that plunders the spirituality of the people, in that, that the author hates socialism mainly for the missed opportunities in terms of readings, exhibitions and screenings of films, and the missed opportunities for a „quality rise" in the Self.

Unlike other East European literatures, where the nature of communism is a constant theme in the texts of dissident writers such as Czesław Miłosz, Václav Havel and Milan Kundera, Bulgarian literature from the time of communism demonstrated weak powers of resistance. And even when it did try to resist, it did so using Aesopian allegories, and therefore, its dissident behaviour remained rather hidden, rather quiet. That accounted largely for the boom in rethinking of the past in the years of freedom, as well as of the compensatory mechanisms Bulgarian literature developed, some of which were covered in this essay. 